\title{
NAS ONDAS DO RÁDIO
}

\section{Erroneamente se imagina o rádio como um veículo antigo e}

ultrapassado; puro engano: agilidade, criatividade e larga abrangência garantem que ele continue embalando sonhos e servindo a muita gente

"A televisão vende a imagem, o rádio a imaginação". Esta foi uma das primeiras frases que ouvi, quando coloquei os pés pela primeira vez em uma emissora de rádio. Mas, antes disso, tive um longo caminho a trilhar. Formei-me em Jornalismo em 1985, já estagiava na Secretaria de Cultura, na Assessoria de Imprensa, e tinha uma grande paixão, trabalhar no jornalismo impresso. Comecei a fazer free lancer em várias revistas, até ser contratada como assistente de redação da revista Somtrês. A gente fica deslumbrada com o impresso, o acompanhamento da matéria, a fotografia ilustrando seu trabalho etc. Mais tarde fui contratada como repórter da revista Afinal. Sair com fotógrafo, dar flagrantes e fazer matérias exclusivas é o que todo profissional quer.

Os primeiros cinco anos de experiência jornalística foram assim. Muito aprendizado. Burilar palavras, copidescá-las ${ }^{1}$, sonhar com grandes textos. Tudo no começo é tênue e poético.

Em 89, cansada de entrar e sair de projetos que não se concretizavam, muito até em função da instabilidade econômica do país, resolvi atacar em outro veículo. Desempregada, fui conversar com uma amiga na TV Gazeta, que estava no auge com o projeto TV Mix.

Projeto pioneiro, revolucionário, envolvente... Na profissão de jornalista, isso tem que ser mesmo um traço forte, o da ousadia, de pensar grande, de ir a fundo nas questões. Só que, às vezes, não é bem assim que acontece. $\mathrm{O}$ aluno geralmente sai da faculdade e nem sempre as portas se abrem para o que ele realmente deseja.

$\mathrm{Na}$ TV senti aquele clima de euforia, gente correndo pelos corredores, o fascínio do ego dilatado pela câmera de estúdio.

\section{A VOZ}

Não, não era para mim, não estava na hora. Fui parar na

\section{A AUTORA \\ Cristina Braga \\ Radialista da Rádio Gazeta, em São Paulo.}

1. Termo usado no jornalismo; significa reescrever, acertar, reordenar, corrigir um texto, adequando-o às regras gramaticais e às normas dos manuais, visando a sua publicação. 
Rádio Gazeta, onde Alberto Helena Júnior tinha acabado de assumir a direção e estava contratando redatores para os novos programas. Estava na hora certa e no local certo. Fui contratada como redatora do jornalismo.

Era um campo novo, esse de escrever para rádio. Tudo rápido, tudo manchetado, resumido. A maior dificuldade que o redator sente é que o texto tem de ser curto. Ser prolixo, se alongar muitas vezes é mais fácil.

Fui escrevendo, recebia as notícias das agências, via telex, na época, e as resumia. Mais tarde fui fazendo entrevistas curtas pelo telefone, grande vantagem do rádio em relação à TV, recebia as pautas e ia desenvolvendo as matérias. Era interessante e instigante, li muito e ia atrás dos fatos locais. Mais tarde, pediram-me para gravar boletins e aí foi terrível. Tinha que usar a cabeça, as mãos e agora... um dado novo: a voz.

Como eu poderia falar no rádio? Que sensação horrível, se ouvir pela primeira vez! Não, não dá... acho mesmo que vou ficar somente como redatora. Foi aí que recebi um conselho: "treinar é a solução".

Com o passar do tempo, a voz foi ficando mais aveludada e passei a me ouvir, e até a aceitar a minha voz. Os profissionais que trabalham em rádio têm que gostar da sua voz. É a sua assinatura, é a marca. O radialista por sua vez tem a voz marcada, pontuada e treinada, já que faz um curso específico para a colocação da voz e não precisa necessariamente de um curso superior.

Depois, com o tempo fiz, produção de vários programas dentro da emissora e nos últimos dois anos apresentei dois programas. O passo para apresentadora-locutora foi inesperado. De repente, o apresentador do programa faltou e eu tive de substituí-lo. Assim de repente apresentei o Sucesso Gazeta, um programa jornalístico vespertino. Aí experimentei um outro tipo de emoção: a dos ouvintes telefonando para me conhecer, saber da minha pessoa, da locutora; senti-me fazendo parte do cotidiano do público ouvinte.

Nunca, na verdade, um veículo de comunicação aproxima tanto o jornalista de seu público quanto o rádio. É o poder da mensagem, parafraseando o grande radialista Hélio Ribeiro.

\section{A SEGMENTAÇÃo}

É isso que fui percebendo. Tudo o que se transmite tem uma repercussão imediata. $\mathrm{O}$ ouvinte liga para a emissora e participa. $\mathrm{O}$ rádio é um veículo interativo por excelência. 
Por outro lado, os ossos do ofício também foram se delineando. A tendência do rádio, na minha opinião, é a segmentação. Uma emissora para cada perfil, a exemplo dos Estados Unidos, que mantêm em todo o país dez mil emissoras de rádio, quase todas segmentadas.

Uma rádio que aborde esporte, outra só jornalismo e nesse filão até mesmo as evangélicas, que acabam ocupando um bom espaço no dial.

Paralelamente à questão da segmentação, temos também o sucateamento das redações. $\mathrm{Na}$ verdade, um aluno quando se forma nunca pensa em trabalhar em rádio. De dez, nove querem ir para a Folha de S. Paulo ou para a TV Globo.

Nada mal, hein? Brincadeiras à parte, o rádio para a nova geração que ainda cursa a faculdade é um veículo ultrapassado, o público tem algumas exigências estéticas que, por exemplo, o AM não atende; como o som. O adolescente de hoje está acostumado ao som digital, daí a problemática de ouvir o som AM, por mais estéreo que seja. Procura-se o rádio só para prestações de serviço, como o movimento de estradas, previsão do tempo, trânsito e futebol, no máximo. Programas musicais ficam para a FM. E o adolescente de hoje, amanhã vira jornalista.

Na televisão, você tem a imagem contextualizada, consegue transportar as pessoas para o fato; no rádio, tem que usar a imaginação. A tendência do público é de eleger o rádio como entretenimento apenas, por isso o crescimento das FMs.

Mas o grande barato de trabalhar em rádio talvez seja isso tudo, essa instantaneidade; de um telefone fala-se com o mundo, o fato está acontecendo e o repórter pode através de uma linha se comunicar com a redação e narrar a notícia. E, falou: repercutiu...

Se, por um lado, os baixíssimos salários dos profissionais que atuam nessa área não animam muito os que estão chegando no mercado de trabalho, e aí a meu ver está a questão principal, por outro lado, quem já trabalhou em rádio nunca esquece. Não é raro a gente observar em emissoras que locam seu espaço, radialistas comprando horário para ter seu próprio programa. Isso acontece muito em rádios do Interior. Como os salários são pequenos, os patrocinadores bancam o programa. Saem lucrando a emissora e o radialista.

Hoje noto também, em quase sete anos de experiência, a alta rotatividade em rádio. $\mathrm{O}$ profissional vem para as redações como última opção, fica por um tempo e depois não se adapta com o for- 
mato, a linguagem e o salário, ou então acaba sendo cortado, já que o rádio precisa sempre aferir sua audiência, fazendo ajustes na programação.

A princípio parece fácil trabalhar com o veículo. No entanto, é preciso gostar muito, adaptar-se muito, para ficar tanto tempo em uma mesma emissora. Normalmente, a maioria dos radialistas e jornalistas que estão nas rádios, trabalham em outros lugares. Refirome aos locutores que precisam completar sua renda fazendo locução de comercial etc. A não ser que sejam voz padrão de emissora, e que tenham contrato com exclusividade.

O rádio, no entanto, tem a sua magia. Teve seus anos dourados, na década de 50. Quantos programas de auditório lançaram ídolos que marcaram gerações! A própria Rádio Gazeta, na década de 40/50, era considerada a emissora de elite. Ela tinha programas com orquestras sinfônicas, gravava discos e privilegiava os músicos, a música ao vivo.

Esses programas de auditório ainda foram revitalizados em algumas emissoras, nos últimos anos, mas não vingaram.

Como ouvinte, que também sou, o rádio faz-me companhia. Somos cúmplices dos diálogos, estamos ali ouvindo o apresentador entrevistar duas ou três pessoas ao mesmo tempo. Participamos dessa conversa. Quando estou em casa, estou sempre com o rádio ligado, até para apreciar o trabalho dos companheiros.

\section{RESPEITO AO REGIONAL}

Incrível mesmo é sair pelo Brasil afora e ver que em muitas cidades do Interior desse nosso Brasil o que move seus habitantes são os programas característicos e regionais. É a identificação total de sua cultura retratada na emissora local. E, em muitas ocasiões, o que vale mesmo é o esquema de alto falante na praça.

Algumas vezes, quando apresentava o Sucesso Gazeta, recebia muitos telefonemas de ouvintes do Paraná, Minas Gerais e de diversos Estados. É que a Gazeta pode ser sintonizada também em ondas curtas (19, 31 e 49 metros). Ficava surpresa com cartas e telefonemas. Perguntava qual o interesse em receber a nossa programação e eles respondiam que curtiam nossos programas, queriam se inteirar do que acontece em São Paulo e que também eram ouvintes assíduos. Em ondas curtas é possível pegar a BBC de Londres e até a Rádio de Moscou, entre outras. 
Sensibilizada fiquei mesmo quando comecei a receber telefonemas e correspondências de pessoas solitárias, cuja única companhia era o rádio e o locutor. $O$ rádio, para eles, fazia parte de sua vida, era como um membro da família, e o locutor um paciente confidente de seus problemas.

O rádio é mesmo aquele fio condutor que prende a todos nas ondas, que embala em melodias amorosas e saudosas.

É um catalisador de emoções. É por isso que dá a liga. Depois de sair de um estádio de futebol, há que se ligar o rádio, e ouvir a explosão do locutor. Que gol tem tanta força quanto aquele que sai pelos poros do rádio de pilha ou do carro?

Valorizar mais o profissional, remunerar melhor para que a qualidade vença, sobretudo em um fututo promissor para o veículo e o ouvinte, porque tenho certeza de que uma TV pode faltar em uma casa, mas um radinho de pilha não.

Seja por entretenimento, companhia ou informação, o rádio não perderá nunca seu papel como meio de comunicação de massa. Poderá se adaptar quanto à programação e estilos, mas não pode deixar morrer essa magia, de vender a imaginação, o poder da reflexão, coisa rara hoje em dia. 